\title{
Genomic Tools in Cowpea Breeding Programs: Status and Perspectives
}

\author{
Ousmane Boukar ${ }^{1 *}$, Christian A. Fatokun ${ }^{2}$, Bao-Lam Huynh ${ }^{3}$, Philip A. Roberts ${ }^{3}$ and \\ Timothy J. Close ${ }^{4}$
}

${ }^{1}$ Cowpea Breeding, International Institute of Tropical Agriculture, Kano, Nigeria, ${ }^{2}$ Cowpea Breeding, International Institute of Tropical Agriculture, Ibadan, Nigeria, ${ }^{3}$ Department of Nematology, University of California, Riverside, Riverside, CA, USA,

${ }^{4}$ Department of Botany and Plant Sciences, University of California, Riverside, Riverside, CA, USA

OPEN ACCESS

Edited by:

Janila Pasupuleti, International Crops Research Institute for the Semi Arid Tropics, India

Reviewed by:

Manish Kumar Pandey,

International Crops Research Institute

for the Semi-Arid Tropics, India

Caiguo Zhang,

University of Colorado, Denver, USA

${ }^{*}$ Correspondence:

Ousmane Boukar

o.boukar@cgiar.org

Specialty section:

This article was submitted to

Plant Genetics and Genomics,

a section of the journal

Frontiers in Plant Science

Received: 11 December 2015

Accepted: 17 May 2016

Published: 03 June 2016

Citation:

Boukar O, Fatokun CA, Huynh B-L,

Roberts PA and Close TJ (2016) Genomic Tools in Cowpea Breeding Programs: Status and Perspectives.

Front. Plant Sci. 7:757. doi: 10.3389/fp/s.2016.00757
Cowpea is one of the most important grain legumes in sub-Saharan Africa (SSA). It provides strong support to the livelihood of small-scale farmers through its contributions to their nutritional security, income generation and soil fertility enhancement. Worldwide about 6.5 million metric tons of cowpea are produced annually on about 14.5 million hectares. The low productivity of cowpea is attributable to numerous abiotic and biotic constraints. The abiotic stress factors comprise drought, low soil fertility, and heat while biotic constraints include insects, diseases, parasitic weeds, and nematodes. Cowpea farmers also have limited access to quality seeds of improved varieties for planting. Some progress has been made through conventional breeding at international and national research institutions in the last three decades. Cowpea improvement could also benefit from modern breeding methods based on molecular genetic tools. A number of advances in cowpea genetic linkage maps, and quantitative trait loci associated with some desirable traits such as resistance to Striga, Macrophomina, Fusarium wilt, bacterial blight, root-knot nematodes, aphids, and foliar thrips have been reported. An improved consensus genetic linkage map has been developed and used to identify QTLS of additional traits. In order to take advantage of these developments single nucleotide polymorphism (SNP) genotyping is being streamlined to establish an efficient workflow supported by genotyping support service (GSS)-client interactions. About 1100 SNPs mapped on the cowpea genome were converted by LGC Genomics to KASP assays. Several cowpea breeding programs have been exploiting these resources to implement molecular breeding, especially for MARS and MABC, to accelerate cowpea variety improvement. The combination of conventional breeding and molecular breeding strategies, with workflow managed through the CGIAR breeding management system (BMS), promises an increase in the number of improved varieties available to farmers, thereby boosting cowpea production and productivity in SSA.

Keywords: cowpea, genomics, marker-assisted breeding, Vigna unguiculata, blackeye pea

\section{ECONOMIC IMPORTANCE, GROWING REGIONS, NUTRITIONAL VALUE}

Globally, cowpea is an important grain legume adapted and grown in dry areas of the tropics and subtropics. In sub-Saharan Africa (SSA), cowpea plays an important role in both human nutritional and food security and income generation for farmers and food vendors. Its grains are rich in protein, carbohydrates and folic acid, and contain respectable amounts of some minerals. 
Young cowpea leaves are used as spinach in eastern and southern Africa while green immature pods and green mature seeds are also used in Senegal and some other African countries. The most economically important part of the crop remains the dry grain, which is commonly boiled and eaten as beans. The grain can be processed as flour or paste, which is used to make akara (deep-fried) or moin-moin (steamed), eaten as snacks in several western and central African countries. Based on evaluation of 1541 germplasm lines, Boukar et al. (2011) reported that cowpea grains contain on average $25 \%$ protein, $53.2 \mathrm{mg} / \mathrm{kg}$ iron, 38.1 $\mathrm{mg} / \mathrm{kg}$ zinc, $826 \mathrm{mg} / \mathrm{kg}$ calcium, $1915 \mathrm{mg} / \mathrm{kg}$ magnesium, 14,890 $\mathrm{mg} / \mathrm{kg}$ potassium, and $5055 \mathrm{mg} / \mathrm{kg}$ phosphorus. In addition to the grain, the biomass (haulms) from cowpea plants provides important nutritious fodder for ruminants mainly in the Sahel regions of West and Central Africa. Through its ability to fix atmospheric nitrogen, cowpea, like other legumes, contributes to the fertility of soil. Cowpea fixes between 70 and $350 \mathrm{~kg}$ nitrogen per hectare and contributes $40-80 \mathrm{~kg}$ nitrogen/ha to the soil (Quin, 1995). The estimated potential impact of cowpea research on fixed nitrogen in SSA, for the period 2011-2020 would be about 77,320 tons (CRP GL, 2012).

Although accurate statistics are generally unavailable, cowpea production worldwide is estimated at about 6.5 million metric tons annually on about 14.5 million hectares. About $83 \%$ of the global cowpea production is obtained in Africa, with over $80 \%$ of African production in West Africa. Nigeria, with an estimated $45 \%$ of the world cowpea production and over $55 \%$ of the production in Africa, is the world's largest producer and consumer of cowpea, followed by Niger (15\%), Brazil (12\%), and Burkina Faso (5\%). Over the last three decades, global cowpea production grew at an average rate of $5 \%$, with $3.5 \%$ annual growth in area and $1.5 \%$ growth in yield, and the area expansion accounting for $70 \%$ of the total growth during this period (Fatokun et al., 2012b). Globally, the share of cowpea in total area under pulses grew from $<10 \%$ in 1990 to nearly $20 \%$ in 2007. In West Africa, cowpea occupies over $85 \%$ of the area under pulses and $10 \%$ of the total cultivated land (Fatokun et al., 2012b). If these past trends in cowpea area expansion and yield continue into the future, the global cowpea supply is projected to reach 9.8 million tons in 2020 and 12.3 million tons in 2030, against the projected global demand of nearly 8.5 million tons in 2020 and 11.2 million tons in 2030. Increased investments in research are needed to generate an increase in yield to meet the projected increasing demand for the crop and to forestall any possible deficit. Through the sales of cowpea products, smallholder farmers in SSA generate some income despite the fact that information about cowpea trade is very scanty. Abate et al. (2012) attributed this lack of information to the limited international trade involving cowpea.

\section{PRODUCTION CONSTRAINTS}

The production of cowpea is limited by several biotic and abiotic stresses. The biotic stresses include insect pests, diseases, parasitic weeds, and nematodes. At every stage in the life cycle of the crop there is at least one major insect pest that may cause yield losses. Aphid (Aphis craccivora) attacks cause the highest amount of damage to the plants mainly at the seedling stage. Flower bud thrips (Megalurothrips sjostedti) at flowering stage cause the destruction of flower buds and failure of pod formation. Pods and young shoots are destroyed by pod borers (Maruca vitrata) while a complex of pod-sucking bugs (Clavigralla tomentosicollis, Anoplocnemis curvipes, Nezara viridula) penetrate and damage seeds in pods. In storage, bruchid weevils (Callosobruchus maculatus) cause serious damage to the grains.

In the case of diseases, cowpea is attacked by bacteria, viruses, fungi, and nematodes. Bacterial blight caused by Xanthomonas vignicola and bacterial pustule (Xanthomonas sp.) are the main bacterial diseases of cowpea. Several viruses infect cowpea including Cowpea aphid-borne mosaic virus (CABMV, genus Potyvirus, family Potyviridae); Bean common mosaic virus-blackeye cowpea mosaic strain (BCMV-BlCM, genus Potyvirus, family Potyviridae); Cowpea mosaic virus (CPMV, genus Comovirus, family Secoviridae); Southern bean mosaic virus (SBMV, genus Sobemovirus); Cowpea mottle virus (CPMoV, genus Carmovirus, family Tombusviridae); Cucumber mosaic virus (CMV, genus Cucumovirus, family Bromoviridae); Cowpea mild mottle virus (CPMMV, genus Carlavirus, family Betaflexiviridae); and Cowpea golden mosaic virus (CGMV, genus Begomovirus, family Geminiviridae). The main fungi known to cause diseases in cowpea plants include Colletotrichum sp. causing anthracnose and brown blotch, Macrophomina phaseolina causing charcoal rot, ashy stem blight and stem canker, Cercospora canescens causing cercospora leaf spot, Elsinoe phaseoli causing scab, and Rhizoctonia solani causing web blight. Plant-parasitic nematodes, especially root-knot nematodes (Meloidogyne spp.), damage cowpea root systems and cause yield suppression in many cowpea production areas. These diseases may occur singly or in combinations of two or more pathogens, and in some cases are strongly influenced by the growing environment, for example, ashy stem blight caused by Macrophomina is much more prevalent and severe in droughtstressed cowpea plantings.

Parasitic weeds, Striga gesnerioides and Alectra vogelii, can cause significant damage to cowpea production. Striga is mainly present in the dry savannah areas of West and Central Africa while Alectra is found predominantly in eastern and southern Africa.

Abiotic stresses affecting cowpea production include drought, heat, and low soil fertility. Although the crop is known to be drought tolerant, its yield can be reduced significantly when exposed to seedling, mid-season or terminal drought. Heat may cause serious damage during the off-season cropping. High night temperatures lead to flower abortion thereby preventing pod formation and a consequent reduction in grain yield. Soils that are deficient in phosphorous, an element required for nitrogenfixation in legume root nodules, may lower the productivity of cowpea.

\section{GENETIC LINKAGE GROUPS, BREEDING BEHAVIOR, WILD SPECIES}

Cowpea is a diploid with $2 n=22$. Thus, there are 11 linkage groups as revealed by several reports on genetic linkage mapping based on molecular markers. More details about the development 
and current status of cowpea linkage groups are provided in Section Available Genomic Resources of this review.

Cowpea is a highly self-pollinating crop. The extent of outcrossing is therefore low and varies with environment. The development of improved varieties has been mainly through pure line selection, mass selection, pedigree breeding, singleseed descent, and backcross methods. The genetic base of most of the improved varieties that have been released to farmers for planting is narrow. This is no surprise because improved lines are mostly used as parents in developing populations from which new varieties are derived. In the study reported by $\mathrm{Li}$ et al. (2001), the level of SSR polymorphism among improved breeding lines was found to be low when compared with those lines generated using newly acquired germplasm lines as parents. The need for varieties with broad genetic base in farmers' fields should be given priority attention in SSA cowpea breeding programs.

Cowpea belongs to the genus Vigna, comprised of several sections, species, sub-species, and varieties. Cowpea belongs to section Catiang, species unguiculata, sub-species unguiculata. All cultivated cowpea and its close cross-compatible relatives belong to Vigna unguiculata (Marechal et al., 1978). Three wild subspecies of $V$. unguiculata, namely subspecies dekindtiana or spontanea, subspecies stenophylla and subspecies tenuis are recognized. Several taxonomists have proposed different subspecies and names for some of the cowpea wild relatives. There appears to be no consensus yet on the proper classification of the cowpea wild relatives and this has complicated efforts to define the primary and secondary gene pools for cowpea. It should be noted that varying levels of success have been achieved in efforts to make crosses between members of subspecies belonging to V. unguiculata. Fatokun and Singh (1987) had to apply embryo rescue in order to successfully cross a cultivated cowpea line with the wild relative $V$. unguiculata subspecies pubescens. The hybrid that was rescued through in vitro culture was partially fertile. In the several crosses that have been made between cowpea and its wild relatives, the hybrids always showed varying levels of partial fertility. Backcrossing of the hybrids to cultivated cowpea should however improve the level of fertility in subsequent generations. A major drawback to the use of wild cowpea relatives in cowpea breeding is the small seed-size associated with the wild forms. Since small seedsize is dominant to large seed several backcrosses are required in order to recover the desired seed-size of the cultivated type. This is necessary because consumers prefer large seed-size. The application of now available molecular marker tools (Table 1) should facilitate progress in rapid recovery of the genome of the cultivated parental lines.

\section{TARGET TRAITS}

To alleviate the devastations caused by numerous cowpea production constraints, breeding programs in SSA and USA are implementing both molecular and conventional breeding to develop improved lines with high grain yield potential, resistance to biotic stresses, tolerance to abiotic factors, adaptation to major production agro-ecologies, and traits preferred by consumers and producers.

Sources of genes for several of these traits have been identified through screening of the germplasm available in different countries. The International Institute of Tropical Agriculture (IITA) is maintaining in its genetic resources center about 15,000 accessions of cultivated cowpea and more than 2000 wild relatives. Mining these resources has resulted in the identification of several sources of resistance to biotic and abiotic stresses. Several authors have reported on those germplasm lines that are important sources of resistance for use in breeding programs (Ferry and Singh, 1997; Singh, 2002; Boukar et al., 2015).

Sources of new traits continue to be identified in cowpea germplasm, and the traits defined at high genetic resolution with the new genotyping resources available for identifying markertrait associations as described in more detail in Section MarkerTrait Associations. As recent examples, Souleymane et al. (2013) confirmed the tolerance to aphids of the improved line IT97K556-6, in which two resistance loci were mapped (Huynh et al., 2015) and also identified a new source of aphid resistance from a cowpea wild relative, TVNu 1158. The cowpea accession "Sanzi" was identified as a source of genes for resistance to flower bud thrips in Nigeria, Mali and Cameroon. A recent screening of about 200 accessions identified TVu 1272 from Uganda and TVu 16514 from Nigeria as resistant to S. gesnerioides. Out of 1300 accessions screened for drought tolerance, 20 were identified with higher levels of tolerance than others (Fatokun et al., 2012a). Six of these accessions have been used in multiple crosses including Danila, TVu 557, TVu 1438, TVu 4574, TVu 6443, and TVu 11982. A set of 1541 cowpea germplasm lines were evaluated for the content of protein and minerals $(\mathrm{Fe}, \mathrm{Zn}, \mathrm{Mg}, \mathrm{Ca}$, and $\mathrm{K}$ ) in grains (Boukar et al., 2011). Lines rich in grain protein included TVu 10425 (32.2\%), TVu 2822 (31.8\%), TVu 16531 (31.3\%), TVu 450 (31.1\%), and TVu 16616 (31.0\%). Lines exhibiting high levels of Fe included TVu $2723(79.5 \mathrm{mg} / \mathrm{kg})$, TVu $14878(79.5 \mathrm{mg} / \mathrm{kg})$, TVu $2852(78.7 \mathrm{mg} / \mathrm{kg})$, TVu $526(78.1 \mathrm{mg} / \mathrm{kg})$, and TVu 10342 $(77.0 \mathrm{mg} / \mathrm{kg}$ ). Lines with high zinc content were TVu 10342 (58.0 $\mathrm{mg} / \mathrm{kg})$, TVu 1732 (56.1 mg/kg), TVu 9576 (55.3 mg/kg), TVu $2651(54.5 \mathrm{mg} / \mathrm{kg})$, and TVu $1877(54.0 \mathrm{mg} / \mathrm{kg})$. Interestingly, lines with high iron content were also rich in zinc and protein content, implying that these desirable minerals could be selected for concurrently in breeding programs to develop nutrient dense improved varieties.

These genetic sources of desirable traits have been used in hybridization programmes to generate several segregating populations, which were used to select plants with good combinations of target traits (high yield potential, resistance to biotic and abiotic stresses, and consumer preferences). Different breeding methods applicable to self-pollinated crops are employed in cowpea genetic improvement including mass selection and pure line breeding, pedigree selection, single seed descent, bulk selection, backcrossing, mutation breeding, and farmer-participatory varietal selection. Generally, combinations or modifications of these breeding methods are also adopted as necessary. More than 20 IITA breeding lines were released in about 10 countries from 2005 to 2015 (Table 2). Many of the varieties combine high grain yield with resistance to Striga 
TABLE 1 | Some cowpea genomics resources.

\begin{tabular}{|c|c|c|c|}
\hline Resources & Short description & Use & References \\
\hline $\begin{array}{l}\text { Physical Map of } \\
\text { cowpea }\end{array}$ & $\begin{array}{l}60,000 \text { BACs from IT97K-499-35 were } \\
\text { fingerprinted. The final physical map is an } \\
\text { assembly of } 43,717 \text { BACs with a depth of } 11 \times \\
\text { genome coverage. }\end{array}$ & Tool for gene discovery & $\begin{array}{l}\text { Close et al., 2011; http://phymap. } \\
\text { ucdavis.edu:8080/cowpea/ }\end{array}$ \\
\hline HarvEST:Cowpea & $\begin{array}{l}\text { EST database with gene function analysis and } \\
\text { primer design. }\end{array}$ & Online cowpea genomics browser & $\begin{array}{l}\text { Muchero et al., 2009a,b; } \\
\text { http://harvest.ucr.edu/ }\end{array}$ \\
\hline $\begin{array}{l}\text { Cowpea } \\
\text { Genespace/Genomics } \\
\text { Knowledge Base } \\
\text { (CGKB) }\end{array}$ & $\begin{array}{l}\text { Genetic markers, gene-space, metabolic } \\
\text { pathways, mitochondrial, and chloroplast } \\
\text { sequences. }\end{array}$ & $\begin{array}{l}\text { Tool for gene discovery; enzyme and } \\
\text { metabolic pathway }\end{array}$ & $\begin{array}{l}\text { Chen et al., 2007; http:// } \\
\text { cowpeagenomics.med.virginia.edu/ } \\
\text { CGKB/ }\end{array}$ \\
\hline $\begin{array}{l}\text { The Cowpea } \\
\text { Genomics } \\
\text { Initiative (CGI) }\end{array}$ & Some advances in cowpea genomics. & $\begin{array}{l}\text { Tools for gene discovery and cowpea } \\
\text { improvement }\end{array}$ & $\begin{array}{l}\text { Chen et al., 2007; http:// } \\
\text { cowpeagenomics.med.virginia.edu/ }\end{array}$ \\
\hline Microarray chip & $\begin{array}{l}41,949 \text { EST sequences from drought stressed } \\
\text { and non-stressed drought susceptible and } \\
\text { tolerant cowpea materials generated, } \\
\text { representing 16,954 unigenes. }\end{array}$ & For expression analysis in cowpea & $\begin{array}{l}\text { Contact S. Hearne, CIMMYT, Mexico, } \\
\text { s.hearne@cgiar.org } \\
\text { The ESTs are all available in Harvest } \\
\text { database of cowpea (UCR and } \\
\text { GENBANK on NCBI) }\end{array}$ \\
\hline $\begin{array}{l}\text { Validated SSR } \\
\text { marker kit }\end{array}$ & $\begin{array}{l}\text { Reference kit of } 20 \text { SSRs used to define the } \\
\text { Cowpea Germplasm Reference Set representing } \\
\text { the genetic diversity of the entirety of the IITA } \\
\text { cowpea germplasm bank collection. }\end{array}$ & $\begin{array}{l}\text { For diversity analysis and gene } \\
\text { discovery }\end{array}$ & $\begin{array}{l}\text { Available from Generation Challenge } \\
\text { Program, CIMMYT, Texcoco, Mexico } \\
\text { http://info@generationcp.org }\end{array}$ \\
\hline $\begin{array}{l}\text { Cowpea } \\
\text { consensus } \\
\text { genetic linkage } \\
\text { map }\end{array}$ & $\begin{array}{l}\text { A consensus map containing } 1107 \text { EST- derived } \\
\text { SNP markers ( } 856 \text { bins) on } 11 \text { linkage groups } \\
\text { ( } 680 \mathrm{cM} \text { ) was constructed from } 13 \\
\text { population-specific maps. }\end{array}$ & $\begin{array}{l}\text { For QTL identification, map-based } \\
\text { cloning, diversity, association } \\
\text { mapping }\end{array}$ & Lucas et al., 2011 \\
\hline Software & $\begin{array}{l}\text { 'SNP Selector', 'KBioConverter', and 'Backcross } \\
\text { Selector' used for the management of } \\
\text { genotyping data. }\end{array}$ & For molecular breeding & $\begin{array}{l}\text { (http://breedit.org/) and } \\
\text { https://www.integratedbreeding.net/ }\end{array}$ \\
\hline
\end{tabular}

and Alectra. An example is the breeding line IT97K-499-35, which has been released in Niger, Nigeria, Ghana, and Mali; many farmers have adopted this line because of its superior performance.

Cowpea is grown mainly for the protein-rich grains for human consumption. There are now cowpea varieties classified as dual purpose because they produce high grain yield as well as high biomass. The biomass of the haulm, which remains after harvest, is a source of quality fodder for ruminant livestock especially in the Sahelian region of SSA. Cowpea is prone to attack by a myriad of insect pests. These insects cause appreciable grain yield reductions if not controlled using insecticides. It is not uncommon for some farmers in the Sahel to make some income selling fodder from their cowpea fields, which may have suffered serious insect damage to grain yield.

M. vitrata is a Lepidopteran insect pest of cowpea. It is the most cosmopolitan of cowpea insect pests and farmers need to apply insecticides to their fields to protect their cowpea crop. Efforts had been made to develop cowpea varieties with resistance to this insect but without success, as there are no resistant lines among accessions of cultivated cowpea. Genetic transformation of cowpea was embarked upon in order to obtain Maruca resistant lines. Popelka et al. (2006) reported successful transformation of cowpea with the $B t$ gene that is efficacious against Maruca. Currently efforts are ongoing to transfer the $B t$ gene to cowpea varieties with high grain yield and farmers' and consumers' preferred attributes.

\section{AVAILABLE GENOMIC RESOURCES}

The development of genomic resources for cowpea has been more recent than those developed for many other crops. Most early efforts in cowpea were focused on molecular diversity and genetic linkage mapping. Genetic diversity studies have used different marker systems as technologies have advanced, including allozymes (Panella and Gepts, 1992; Pasquet, 1999, 2000), seed storage proteins (Fotso et al., 1994), chloroplast DNA polymorphism (Vaillancourt and Weeden, 1992), restriction fragment length polymorphism (RFLP) (Fatokun et al., 1993), amplified fragment length polymorphisms (AFLP) (Fatokun et al., 1997; Tosti and Negri, 2002; Fang et al., 2007), DNA amplification fingerprinting (DAF) (Spencer et al., 2000; Simon 


\begin{tabular}{|c|c|c|}
\hline $\begin{array}{l}\text { Year of } \\
\text { release }\end{array}$ & Variety & Country \\
\hline 2005 & IT93K-452-1, IT90K-277-2 & Nigeria \\
\hline 2008 & IT97K-499-35 & Nigeria \\
\hline \multirow[t]{2}{*}{2009} & IT89KD-288, IT89KD-391 & Nigeria \\
\hline & IT97K-499-35, IT97K-499-38, IT98K-205-8 & Niger \\
\hline \multirow[t]{2}{*}{2010} & IT97K-499-35, IT93K-876-30 & Mali \\
\hline & IT99K-573-1-1 & Niger \\
\hline \multirow[t]{3}{*}{2011} & IT82E-16, IT00K-1263, IT97K-1069-6 & Mozambique \\
\hline & IT99K-494-6 & Malawi \\
\hline & IT99K-573-1-1, IT99K-573-2-1 & Nigeria \\
\hline 2012 & IT99K-7-21-2-2-1, IT99K-573-1-1 & Tanzania \\
\hline \multirow[t]{2}{*}{2013} & IT99K-573-2-1, IT98K-205-8 & Burkina Faso \\
\hline & IT95K-193-12 & Benin \\
\hline \multirow[t]{4}{*}{2015} & IT00K-1263, IT99K-1122 & Tanzania \\
\hline & IT07K-292-10, IT07K-318-33 & Nigeria \\
\hline & $\begin{array}{l}\text { TVx 194801 F, IT05K-321-2, IT97K-390-2, } \\
\text { IT82E-16, IT82E-18, IT99K-494-4 }\end{array}$ & Swaziland \\
\hline & IT99K-573-1-1, IT99K-573-2-1 & Sierra Leone \\
\hline
\end{tabular}

et al., 2007), random amplified polymorphic DNA (RAPD) (Mignouna et al., 1998; Fall et al., 2003; Nkongolo, 2003; Ba et al., 2004; Diouf and Hilu, 2005; Xavier et al., 2005; Zannou et al., 2008), simple sequence repeats (SSRs) (Ogunkanmi et al., 2008; Uma et al., 2009; Xu et al., 2010), cross species SSRs from Medicago (Sawadogo et al., 2010), inter-simple sequence repeats (Ghalmi et al., 2010), sequence tagged microsatellite sites (STMS) (Choumane et al., 2000; Li et al., 2001; Abe et al., 2003; He et al., 2003), and single nucleotide polymorphism (SNP) markers (Huynh et al., 2013). Reports from these studies provide information about origins, taxonomy, domestication, and patterns of genetic variation of cowpea. The development of genome resources in cowpea is now progressing with marker technology advancement.

Linkage mapping provides a framework for downstream analyses including quantitative trait loci (QTL) identification, map-based cloning, diversity analysis, association mapping, and molecular breeding (Lucas et al., 2011). The first linkage map for cowpea was developed using a mapping population of $58 \mathrm{~F}_{2}$ plants derived from a cross between IT84S-2246-4 and TVNu 1963 (Fatokun et al., 1993). The map had 89 loci including 79 RFLP, five RAPD and four cDNA markers as well as one simply inherited morphological trait. These markers were distributed on 10 linkage groups that spanned $680 \mathrm{cM}$ of the cowpea genome. Menendez et al. (1997) developed the second cowpea genetic linkage map using $94 \mathrm{~F}_{8}$ recombinant inbred lines (RILs) derived from a cross between two cultivated genotypes IT84S-2049 and 524B. A total of 181 loci, comprising 133 RAPDs, 19 RFLPs,
25 AFLPs and three each of morphological and biochemical markers were assigned to 12 LGs spanning $972 \mathrm{cM}$ with an average distance of $6.4 \mathrm{cM}$ between markers. This second map was improved with the addition of 242 new AFLP markers, which generated 11 LGs spanning a total of $2670 \mathrm{cM}$, with an average distance of $6.43 \mathrm{cM}$ between markers (Ouédraogo et al., 2002a). A third genetic map was developed using $94 \mathrm{~F}_{8}$ RILs derived from the cross between an improved cultivated cowpea line, IT84S-2246-4, and a wild relative ( $V$. unguiculata spp. dekindtiana var. pubescens) TVNu 110-3A (Ubi et al., 2000). This map consisted of 80 mapped loci (77 RAPD and 3 morphological loci) spanning $669.8 \mathrm{cM}$ of the genome making 12 LGs with an average distance of $9.9 \mathrm{cM}$ between marker loci. With the development of an Illumina GoldenGate Assay, a SNP consensus map with 928 SNP markers on 619 unique map positions distributed over $11 \mathrm{LGs}$, covering a total genetic distance of $680 \mathrm{cM}$ was established based on the genotyping of 741 members of six bi-parental RIL populations derived from the following crosses: $524 \mathrm{~B} \times$ IT84S-2049, CB27 $\times 24-125 \mathrm{~B}-1$, CB46×IT93K-503-1, Dan Ila $\times$ TVu-7778, TVu-14676 $\times$ IT84S2246-4, and Yacine $\times 58-77$ (Muchero et al., 2009a). This first consensus map resulted in a resolution of $0.73 \mathrm{cM}$ average distance between two adjacent markers or 1 SNP per $668 \mathrm{kbp}$ considering the cowpea genome to be $620 \mathrm{Mbp}$. The resolution of this consensus genetic map was improved by genotyping 579 individuals from additional populations consisting of five RILs (from UCR-US, IITA-Nigeria, ISRA-Senegal, ZAAS-China) and two F4 populations (Lucas et al., 2011). This new map contained 33\% more bins (856), 19\% more markers and had an improved order compared to the first consensus genetic map. Updated versions of cowpea consensus maps are accessible via HarvEST:Cowpea (http://harvest.ucr.edu/). Now that linkage maps for cowpea with this marker density are available, there are increased opportunities for QTL resolution, map-based cloning, assessment of genetic diversity, association mapping, and marker-assisted breeding.

The genetic linkage maps that have been published for cowpea are based mainly on molecular markers which are not yet aligned with physical cowpea chromosomes. However, synteny has been reported between cowpea and mung bean (Vigna radiata; Menancio-Hautea et al., 1993) based on RFLP derived separate maps of both crops. These authors also reported that $90 \%$ of the RFLP probes they tested hybridized with both cowpea and mung bean. Some RFLP markers that mapped in both crops were found to be co-linear on linkage groups of the two crops. Lucas et al. (2011) also reported that 941 of 1107 total SNP markers i.e., $85 \%$ that mapped in cowpea show homologs with soybean (Glycine max). The markers also showed synteny and co-linearity in the soybean genome.

\section{Marker-Trait Associations}

Several linkage maps have been used to identify QTLs for desirable traits in cowpea (Table 3). Omo-Ikerodah et al. (2008) used a cowpea linkage map of AFLP and SSR markers to identify QTLs for resistance to flower bud thrips. Gioi et al. (2012) identified and validated a QTL for cowpea yellow mosaic virus (CYMV) resistance using SSR markers. Molecular markers linked 
TABLE 3 | Mapping of some cowpea traits.

\begin{tabular}{|c|c|c|c|c|c|c|c|}
\hline Trait & Population & Type & $\begin{array}{l}\text { Marker } \\
\text { type }\end{array}$ & $\begin{array}{c}\text { No. } \\
\text { markers/QTLs }\end{array}$ & Locations & PV \% & References \\
\hline $\begin{array}{l}\text { Cowpea golden } \\
\text { mosaic virus }\end{array}$ & $\begin{array}{l}\text { IT97 K-499-35 x } \\
\text { Canapu T16 }\end{array}$ & $\mathrm{F}_{2}$ & AFLP & 3 & Same linkage group & & Rodrigues et al., 2012 \\
\hline \multirow[t]{3}{*}{ Striga resistance } & TVx 3236 × IT82D-849 & $F_{2}$ & AFLP & 3 & LG1 & & Ouédraogo et al., 2001 \\
\hline & $\begin{array}{l}\text { Tvu } 14676 \times \\
\text { IT84S-2246-4 }\end{array}$ & $\mathrm{F}_{2}$ & AFLP & 6 & LG 1 & & Ouédraogo et al., 2001 \\
\hline & $\begin{array}{l}\text { IT93 K-693-2 × } \\
\text { IAR1696 }\end{array}$ & $F_{2}$ & AFLP/SCAR & $4 / 1$ & Same linkage map & & Boukar et al., 2004 \\
\hline $\begin{array}{l}\text { Cowpea } \\
\text { bacterial blight } \\
\text { resistance }\end{array}$ & Danlla × TVu7778 & RIL & SNP & 3 & LG3, LG5, LG9 & $10-22$ & Agbicodo et al., 2010 \\
\hline Maturity & IT93K503-1 × CB46 & RIL & AFLP & 2 & LG7, LG8 & $25-29$ & Muchero et al., 2010 \\
\hline Foliar thrips & $\begin{array}{l}\text { CB46 } \times \text { IT93 K-503-1 } \\
\text { and CB27 × IT82E-18 }\end{array}$ & RILs & SNP & 3 & LG2, LG4 and LG10 & $9-32$ & Lucas et al., 2012 \\
\hline Foliar thrips & $\begin{array}{l}\text { CB46 } \times \text { IT93 K-503-1 } \\
\text { and CB27 × IT82E-18 }\end{array}$ & RILs & AFLP & 3 & LG 5 and 7 & $9-32$ & Muchero et al., 2010 \\
\hline $\begin{array}{l}\text { Hastate leaf } \\
\text { shape }\end{array}$ & Sanzi $\times$ Vita 7 & RIL & SNP & 1 & LG 15 & 74.7 & Pottorff et al., 2012a \\
\hline $\begin{array}{l}\text { Domestication- } \\
\text { related } \\
\text { traits }\end{array}$ & $\begin{array}{l}(\mathrm{JP} 81610 \times \mathrm{JP} 89083) \\
\times \mathrm{JP81610}\end{array}$ & $\mathrm{BC}_{1} \mathrm{~F}_{1}$ & SSR & $\begin{array}{l}1-11 \text { for most } \\
\text { traits }\end{array}$ & LG3, LG7, LG8, LG11 & $3-57$ & Kongjaimun et al., 2012b \\
\hline Seed weight & IT2246-4 × TVNul963 & $\mathrm{F}_{2}$ & RFLP & 2 & LG 2 LG6 & $37-53$ & Fatokun et al., 1992 \\
\hline Seed weight & $524 \mathrm{~B} \times 219-01$ & RIL & SSR & 6 & LG1, LG2, LG3, LG10 & $8-19$ & Andargie et al., 2011 \\
\hline $\begin{array}{l}\text { Charcoal rot } \\
\text { resistance }\end{array}$ & IT93 K-503-1 × CB46 & RIL & SNP/AFLP & 9 & LG2, LG3, LG5, LG6, LG11 & $8-40$ & Muchero et al., 2011 \\
\hline $\begin{array}{l}\text { Flower and seed } \\
\text { coat color }\end{array}$ & ZN016 × Zhijiang 28-2 & RIL & $\begin{array}{l}\text { SNP and } \\
\text { SSR }\end{array}$ & 1 each & LG8 & - & Xu et al., 2011 \\
\hline $\begin{array}{l}\text { Time of flower } \\
\text { opening }\end{array}$ & $524 \mathrm{~B} \times 219-01$ & RIL & SSR & 5 & LG1 & $9-30$ & Andargie et al., 2013 \\
\hline Days to flower & $524 \mathrm{~B} \times 219-01$ & RIL & SSR & 3 & LG1 & $6-19$ & Andargie et al., 2013 \\
\hline $\begin{array}{l}\text { Days to first } \\
\text { flowering }\end{array}$ & ZN016 × ZJ282 & RIL & SNP & 3 & LG11, LG10, LG3 & $10-32$ & Xu et al., 2013 \\
\hline
\end{tabular}


TABLE 3 | (Continued)

\begin{tabular}{|c|c|c|c|c|c|c|c|}
\hline Trait & Population & Type & $\begin{array}{l}\text { Marker } \\
\text { type }\end{array}$ & $\begin{array}{l}\text { No. } \\
\text { markers/QTLs }\end{array}$ & Locations & PV \% & References \\
\hline $\begin{array}{l}\text { Nodes to first } \\
\text { flower }\end{array}$ & ZN016 × ZJ282 & $\mathrm{RIL}$ & SNP & 4 & LG11, LG4, LG2, LG6 & $11-22$ & Xu et al., 2013 \\
\hline $\begin{array}{l}\text { Pod number per } \\
\text { plant }\end{array}$ & ZN016 × ZJ282 & RIL & SSR & 3 & LG3, LG2, LG4 & $11-20$ & Xu et al., 2013 \\
\hline Leaf senescence & ZN016 × ZJ282 & RIL & SNP & 2 & LG11, LG3, LG7 & $11-29$ & Xu et al., 2013 \\
\hline $\begin{array}{l}\text { Floral scent } \\
\text { compounds }\end{array}$ & $524 \mathrm{~B} \times 219-01$ & RIL & SSR & 63 & LG1, LG2, LG4 & 60 & Andargie et al., 2014 \\
\hline Heat tolerance & CB27 × IT82E-18 & $\mathrm{RIL}$ & SNP & 5 & LG2, LG7, LG6, LG10, LG3 & $12-18$ & Lucas et al., 2013a \\
\hline Seed size & $\begin{array}{l}\text { Eight different } \\
\text { populations }\end{array}$ & RILs & SNP & 10 & $\begin{array}{l}\text { LG5, LG7, LG2, LG6, LG8, } \\
\text { LG10 }\end{array}$ & 47 & Lucas et al., 2013b \\
\hline $\begin{array}{l}\text { Fusarium wilt } \\
\text { resistance (Fot } \\
\text { race 3) }\end{array}$ & CB27 × 24-125B-1 & RIL & SNP & 1 & LG6 & 28 & Pottorff et al., 2012b \\
\hline \multirow{3}{*}{$\begin{array}{l}\text { Fusarium wilt } \\
\text { resistance (Fot } \\
\text { race 4) }\end{array}$} & IT93K-503-1 × CB46, & $\mathrm{RIL}$ & SNP & 1 & LG8 & $19-47$ & Pottorff et al., 2014 \\
\hline & CB27 × 24-125B-1 & RIL & SNP & 1 & LG9 & $32-40$ & Pottorff et al., 2014 \\
\hline & CB27 × IT82E-18 & RIL & SNP & 1 & LG3 & $18-27$ & Pottorff et al., 2014 \\
\hline Pod tenderness & $\begin{array}{l}(\mathrm{JP} 81610 \times \mathrm{JP} 89083) \\
\times \mathrm{JP} 81610\end{array}$ & $\mathrm{BC}_{1} \mathrm{~F}_{1}$ & SSR & 3 & LG 7, LG8, LG11 & $6-50$ & Kongjaimun et al., 2013 \\
\hline Pod tenderness & JP81610 × JP89083 & $\mathrm{F}_{2}$ & SSR & 2 & LG 7, LG8 & $6-45$ & Kongjaimun et al., 2013 \\
\hline
\end{tabular}

PV \% represents ranges of phenotypic variation of the given QTLs. Adapted and updated from (Abhishek et al., 2014).

to $S$. gesnerioides race-specific resistance genes in cowpea were reported in different studies. Ouédraogo et al. (2001, 2002b) identified three AFLP markers that are tightly linked to the gene designated Rsg2-1 which confers resistance to Race 1 of $S$. gesnerioides in Burkina Faso. The AFLP markers were: E$\mathrm{AAC}_{\mathrm{M}} \mathrm{CAA}_{300}(2.6 \mathrm{cM}), \mathrm{E}-\mathrm{ACT} / \mathrm{M}-\mathrm{CAA}_{524}(0.9 \mathrm{cM})$, and EACA/M-CAT 140/150 (0.9 cM) and they mapped to the lower portion of LG1 published by Menendez et al. (1997). These scientists also reported the identification of six AFLP markers $\left[\mathrm{E}-\mathrm{ACA} / \mathrm{M}-\mathrm{CAG}_{120}(10.1 \mathrm{cM}), \mathrm{E}-\mathrm{AGC} / \mathrm{M}-\mathrm{CAT}_{80}(4.1 \mathrm{cM}), \mathrm{E}-\right.$ ACA/M-CAT $150(2.7 \mathrm{cM}), \mathrm{E}-\mathrm{AGC} / \mathrm{M}-\mathrm{CAT}_{150}(3.6 \mathrm{cM}), \mathrm{E}-$ $\mathrm{AAC} \mathrm{M}-\mathrm{CAA}_{300}(3.6 \mathrm{cM})$, and E- AGC/M-CAT 70 (5.1 cM)] mapped to LG6 and associated with resistance to Striga Race 3 (SG3) from Nigeria. Two of the AFLP markers were associated with resistance to both Striga Races 1 and 3. To facilitate the use of these AFLPs, Ouédraogo et al. (2002a) converted one of these markers to a SCAR (sequence-characterized amplified region) that has been used as an effective and reliable marker in selection for resistance to Striga Races 1 and 3. Boukar et al. (2004) identified two AFLP markers closely linked to resistance to Striga Race 3 from Nigeria, and converted one (E- ACT/M$\mathrm{CAC}_{115}$ located $4.8 \mathrm{cM}$ from the resistance locus) to a SCAR marker to facilitate its use in breeding programs.

In the genetic map published by Ouédraogo et al. (2002a), some resistance genes and biochemical characteristics were mapped. Blackeye cowpea mosaic potyvirus (B1CMV) and southern bean mosaic virus (SBMV) resistance were mapped to LG8 and LG6, respectively, and resistance to cowpea mosaic virus (CPMV) and cowpea severe mosaic virus (CPSMV) were mapped to opposite ends of LG3. The CPSMV resistance mapped near a locus conferring resistance to Fusarium wilt. Ouédraogo et al. (2002a) also mapped resistance to root-knot nematode to one end of LG1 on their genetic map. The biochemical trait dehydrin protein, found in cowpea seed and associated with chilling tolerance at emergence, was mapped to LG2. Agbicodo et al. (2010) identified three QTLs for bacterial blight resistance: CoBB-1, CoBB-2, and CoBB-3 on linkage groups LG3, LG5, and LG9, respectively. The genetic map developed by Ubi et al. (2000) also positioned QTLs for several agronomic and morphological traits, including days to flower, days to maturity, pod length, seeds/pod, leaf length, leaf width, primary leaf length, primary leaf width, and derived traits such as leaf area and primary leaf area.

Two unlinked regions of the cowpea genome carry QTLs explaining $52.7 \%$ of variation in seed weight while four unlinked regions of mung bean carry QTLs accounting for $49.7 \%$ of variation in the same trait (Fatokun et al., 1992). These authors further reported that in both cowpea and mung bean the QTL regions with strong effects on seed weight were spanned by same RFLP markers in the same linkage order. Their study 
thus suggests that this genomic region of cowpea and mung bean has remained conserved in both crops through evolution. The earlier-developed genetic maps described here require additional reconciliation with the new SNP-based linkage maps for positioning key trait determinants.

Recently, SNP-based linkage maps have been used to map several additional traits. From a RIL population developed from a cross between IT93K-503-1 (tolerant) and CB46 (susceptible) differing in their tolerance to seedling-stage drought, 10 QTLs were identified (Muchero et al., 2009b). Some of these QTLs coincided with QTLs for stem greenness (stg) and recovery dry weight $(r d w)$ after drought stress under greenhouse and field conditions. The 10 QTLs were located on LG1, 2, 3, 5, 6, 7, 9, and 10 and accounted for $4.7-24.2 \%$ of the phenotypic variance $\left(R^{2}\right)$. Using the same RIL population, Muchero et al. (2010) identified nine QTLs, accounting for 6.1-40.0\% of the phenotypic variance $\left(\mathrm{R}^{2}\right)$ for resistance to Macrophomina using plant mortality data from 3 years of field experiments and disease severity scores from two greenhouse experiments. QTL Mac-1 was located on LG2, Mac-2, Mac-3, and Mac-4 on LG3, Mac-5 on LG11, Mac6 and Mac-7 on LG5, and Mac-8 and Mac-9 on LG6. This number of QTLs and the relatively low contribution of individual loci suggest a quantitative nature of Macrophomina resistance. Pottorff et al. (2012a) identified a major QTL affecting cowpea leaf shape, which may also influence tolerance to drought. More recently, using phenotypic data from 13 experiments conducted across four countries, Muchero et al. (2013) identified SNPtrait associations based on linkage disequilibrium association mapping, with bi-parental QTL mapping as a complementary strategy. Seven QTLs were associated with stay-green and five of these loci exhibited evidence suggesting pleiotropic effects between delayed senescence, biomass, and grain yield. Among the five putative stay-green QTLs, Dro-1, Dro-3, and Dro7 were identified in both RILs and diverse germplasm, each spanning $3.2 \mathrm{cM}$ or less, suggesting that they may be valuable targets for marker-assisted breeding. Targeting subsets of loci with higher additive effects in marker-assisted breeding would enhance drought tolerance and Macrophomina resistance in economically important cultivars.

For heat stress, Pottorff et al. (2014) identified three QTLs, $H b s-1, H b s-2$, and Hbs-3, associated with heat-induced browning of seed coats using the cowpea RIL populations derived from IT93K-503-1 $\times$ CB46 and IT84S-2246 $\times$ TVu 14676. The identification of SNP markers co-segregating with the heatinduced browning of seed coats phenotype in the Hbs-1 and Hbs3 loci will help indirect selection in breeding cowpea with better quality grain. In addition, the study revealed ethylene forming enzyme as a cowpea candidate gene for the Hbs-1 locus and an ACC synthase 1 gene as a cowpea candidate gene for the Hbs-3 locus.

For cowpea insects, Muchero et al. (2009b) identified three QTLs for resistance to foliar thrips. Thr-1, Thr-2, and Thr-3, were identified on linkage groups 5 and 7 accounting for 9.1$32.1 \%$ of the phenotypic variance. In addition, these authors reported that the peaks of these QTLs are respectively co-located with AFLP markers ACC-CAT7, ACG-CTC5, and AGG-CAT1 that could be used in marker-assisted selection for resistance against foliar thrips. These QTLs were subsequently positioned on a SNP consensus map by Lucas et al. (2012). Huynh et al. (2015) identified one major and one minor QTL conferring aphid resistance on LG 7 and LG 1, respectively, with both of the favorable alleles contributed by IT97K-556-6. The major QTL appeared dominant in a related F2 population. SNP markers flanking each QTL are being used to introgress resistance alleles from IT97K-556-6 into susceptible varieties using markerassisted backcrossing.

A major QTL conferring resistance to root-knot nematodes has been mapped on linkage group 11 of different mapping populations (Huynh et al., 2016). Root-knot nematodes can be a component of disease complexes with other root pathogens such as Fusarium wilt and root rots. Through their efforts to develop Fusarium oxysporum f. sp. tracheiphilum resistant cowpea lines, Pottorff et al. (2012b) mapped a Fot race 3 resistance locus (Fot31) to a $1.2 \mathrm{cM}$ region and identified SNP marker $1 \_1107$ as co-segregating with Fot3-1. Pyramiding QTLs for resistance to root-knot nematodes and fusarium wilt in breeding programs could enable development of cowpea varieties with healthy root systems.

\section{Genome Sequence Efforts in Cowpea}

The genetic map is being used to anchor an initial wholegenome shotgun (WGS) assembly of cowpea accession IT97K499-35, which includes sequences for about $97 \%$ of all known cowpea genes. Genomic DNA from the reference genotype was shotgun sequenced to $\sim 65 \times$ coverage (one 5-kb library included) using Illumina paired-end technology on GAII, and then assembled together with Sanger BAC-end sequences and "gene-space" sequences (Timko et al., 2008) using SOAPdenovo (Luo et al., 2012). The assembly contains $323,048,341 \mathrm{bp}$ of non- $\mathrm{N}$ sequences, with an N50 of 6322. These sequences may be searched by BLAST via harvest-blast.org and downloaded via harvest-web.org. A physical map was developed from BAC libraries of IT97K-499-35 by high information content fingerprinting and computational assembly. This physical map is accessible through http://phymap.ucdavis.edu/cowpea/ and is in the process of being linked to the genetic map and genome sequence. Ongoing work to improve the genome assembly using sequenced BACs, long-read shotgun sequencing and optical mapping is in progress, with a goal of 11 pseudomolecules and an average scaffold length of $56 \mathrm{Mb}$.

\section{THE USE OF GENOMIC TOOLS IN BREEDING PROGRAMS}

During the implementation of the Tropical Legumes I (TLI) project, resources for SNP genotyping and QTL-based selection were developed and applied to marker-assisted recurrent selection (MARS) and marker-assisted backcrossing (MABC) populations (Figure 1). Collaboration between the co-authors, others in the Generation Challenge Program team and LGC Genomics led to conversion of SNP assays to the KASP system. This included 1022 mapped SNPs. Other support tools include the improved cowpea consensus genetic maps (version 


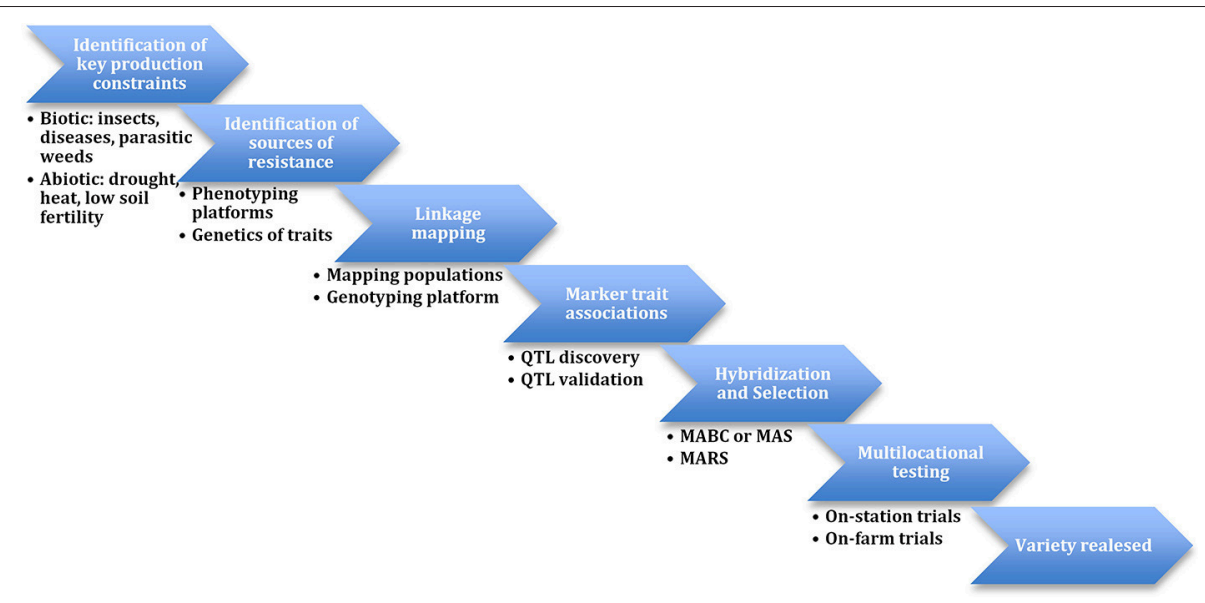

FIGURE 1 | Scheme of molecular breeding in cowpea.

4 in Lucas et al., 2011) and version 6 in HarvEST:Cowpea at http://harvest.ucr.edu/). Development of software including "SNP Selector," "KBioConverter," and "Backcross Selector" (http://breedit.org/) supported the management of genotyping data. The Breeding Management System (BMS) of the Integrated Breeding Platform (IBP) (https://www.integratedbreeding.net/) is currently facilitating the efficient implementation of cowpea molecular breeding.

MARS lines under development were selected from the populations derived from crosses between elite parents in 2010: (1) Suvita $2 \times$ IT97K-499-35 (Burkina Faso), (2) IT84S$2246 \times$ IT98K-1111-1 (Nigeria), (3) CB27 × IT97K-499-35 (Mozambique), and (4) IT93K-503-1 × Mouride (Senegal). These MARS projects aim to accelerate development of lines carrying all identified QTLs in the homozygous favorable allele state. However, different logistical issues occurred from one location to another. MARS lines with the highest molecular scores for target QTLs were tested in the 2014 main season at INERA, Burkina Faso where two cycles of intercross were performed using 164 SNPs polymorphic between the two parents. The traits of interest include grain yield, drought tolerance, Striga resistance and Macrophomina resistance. At IITA, Nigeria, 102 SNPs were used in the development of MARS populations. With the first cycle of intercrosses completed, about 177 plants were fixed for favorable alleles at seven QTLs affecting yield, drought, and staygreen. Advanced breeding lines are being generated and will be tested across several locations in the 2016 main cropping season. At Eduardo Mondlane University (EMU), Mozambique, large seed, grain quality, and tolerance to heat have been the target traits. MARS lines with favorable seed types and fixed for favorable alleles at QTLs are being screened under drought and irrigated conditions. At ISRA, Senegal, about 136 SNPs well distributed across the cowpea genome and polymorphic between the two parents were used. The target traits have been drought tolerance and resistance to Striga, nematodes and Macrophomina. Adjustments that were necessitated by logistical matters resulted in F2:F6 lines being developed and evaluated across locations in Senegal.
Marker-based backcrossing incorporating foreground and background selection has been used to develop lines that are improved versions of local cultivars carrying target traits or QTLs from donors. At INERA, lines Moussa and KVx745-11P are being improved for Striga resistance and seed size, respectively. In the case of Moussa, the donor of Striga resistance was IT93K-693-2, while for KVx745-11P the donor of seed size was KVx414-22. At IITA, IT93K-452-1, and IT89KD-288 are released varieties that are being improved for Striga resistance, and the donor used is IT97K-499-35. At EMU, IT85F-3139 is being improved using CB27 as donor for grain quality and INIA-41 as donor for nematode resistance and drought tolerance. At ISRA, Melakh is being improved using IT97K-499-39 as the donor of Striga resistance. Most MABC populations were developed up to $\mathrm{BC} 3 \mathrm{~F} 4$. MABC lines carrying donor alleles and the highest recurrent parent background were evaluated in INERA during the 2014 main season. Other programs are at different levels of seed increase for field evaluations in 2016.

There have also been efforts within the West African Cowpea Consortium (WACC), funded by Kirkhouse Trust, targeting the development by MABC of new cowpea varieties with resistance to the parasitic weed $S$. gesnerioides in six countries.

In Senegal, ISRA at Bambey is applying MAS in breeding new resistant varieties of cowpea to Striga, aphid, and Macrophomina root rot. In Mali, the Institut d'Economie Rurale (IER) at Bamako is using molecular breeding to develop cowpea lines resistant to the two prevalent strains of Striga present in Mali. In Burkina Faso, INERA at Ouagadougou is using MAS to develop cowpea varieties with resistance to Striga and possessing farmer's preferred traits in different ecological zones. The project has reported the release of four varieties with Striga resistance to farmers in Burkina Faso. Efforts are continuing to apply MAS to develop Striga-, aphid-, and Colletotrichum capsicii-resistant cowpea lines. In Ghana, the Savanna Agricultural Research Institute (SARI) at Tamale is using MAS to introgress aphid resistance into known Striga resistant varieties. In Nigeria, the University of Agriculture Makurdi (UAM) is using MAS to 
develop varieties resistant to Striga, Alectra, aphid, and Fusarium wilt. In Cameroon, the Institut de la Recherche Agronomique pour le Developpement (IRAD) at Maroua is also targeting the development of Striga, aphid, and thrips resistant varieties using MAS.

\section{PERSPECTIVES}

Progress in the development of genomic resources for cowpea was achieved recently through the CGIAR Generation Challenge Programme's (GCP) “Tropical Legumes I" project. A highthroughput SNP genotyping platform was established through this project (Muchero et al., 2009a). This platform genotypes simultaneously 96 DNA samples at 1536 SNP loci. Using this, a consensus genetic map was established, which provides the opportunity of determining marker positions with some precision across the cowpea genome. This will facilitate markertrait association analyses needed for marker-assisted breeding. Currently, efforts are underway to improve both the robustness of the genotyping and the utility of the consensus genetic map through a Feed the Future project entitled, "Innovation Lab for Climate Resilient Cowpea." Fingerprinting of cowpea breeding programs' preferred accessions are ongoing using nearly 50,000 SNPs. As described above in the genomic resources section, SNP markers and QTLs have been identified for some key biotic and abiotic stresses. Molecular breeding approaches have been initiated in some cowpea breeding programs using LGC Genomics, which converted about 1100 mapped SNPs for use with the KASP platform. Efforts will continue to generate more trait-linked markers, which are intended for breeding applications. The availability of facile genotyping platforms, which may proceed by outsourcing, will accelerate QTL discovery for important traits of cowpea. We anticipate that cowpea breeders will use molecular breeding routinely for the foreseeable future to harness important traits from wild and nonadapted cowpea accessions available in genetic resources centers. Through the implementation of modern breeding, improved lines with higher yield potential may be developed more efficiently.

To increase success, cowpea breeding programs need to address additional challenges, the most significant of which is phenotyping. Phenotyping approaches need to be high-throughput, cost-effective, and precise. Data handling and analysis, and decision support tools such as the BMS of the IBP need to be available to and utilized by cowpea breeders. Also, as discussed by others (Varshney et al., 2014), we must integrate training across scientific fields, including genetics, plant breeding, computer science, mathematics, engineering, biometrics and bioinformatics, and evolve new

\section{REFERENCES}

Abate, T., Alene, A. D., Bergvinson, D., Shiferaw, B., Silim, S., Orr, A., et al. (2012). Tropical Grain Legumes in Africa and South Asia: Knowledge and Opportunities. Nairobi: International Crops Research Institute for the Semi-Arid Tropics. forms of communication and professional organizations so that genomics-assisted breeding can achieve its potential.

\section{SUMMARY}

Cowpea is one of the most important grain legumes in SSA. It provides strong support to the livelihood of small-scale farmers through its contributions to their nutritional security, income generation and soil fertility enhancement. Worldwide about 6.5 million metric tons of cowpea are produced annually on about 14.5 million hectares. The low productivity of cowpea is attributable to numerous abiotic and biotic constraints. The abiotic stress factors comprise drought, low soil fertility, and heat while biotic constraints include insects, diseases, parasitic weeds, and nematodes. Cowpea farmers also have limited access to quality seeds of improved varieties for planting. Some progress has been made through conventional breeding at international and national research institutions in the last three decades. Cowpea improvement could also benefit from modern breeding methods based on molecular genetic tools. A number of advances in cowpea genetic linkage maps, and QTL associated with some desirable traits such as resistance to Striga, Macrophomina, Fusarium wilt, bacterial blight, root-knot nematodes, aphids, and foliar thrips have been reported. An improved consensus genetic linkage map has been developed and used to identify QTLs of additional traits. In order to take advantage of these developments SNP genotyping is being streamlined to establish an efficient workflow supported by genotyping support service (GSS)-client interactions. About 1100 SNPs mapped on the cowpea genome were converted by LGC Genomics to KASP assays. Several cowpea breeding programs have been exploiting these resources to implement molecular breeding, especially for MARS and MABC, to accelerate cowpea variety improvement. The combination of conventional breeding and molecular breeding strategies, with workflow managed through the CGIAR BMS, promises an increase in the number of improved varieties available to farmers, thereby boosting cowpea production and productivity in SSA.

\section{AUTHOR CONTRIBUTIONS}

OB and CF have contributed in the design, write up, review, and approval of the final version of the manuscript. $\mathrm{BH}$ has worked on sections Marker-Trait Associations and The Use of Genomic Tools in Breeding Programs, reviewed and approved the final version of the manuscript. TC has provided information in Section Genome Sequence Efforts in Cowpea. In addition, PR and TC have edited, reviewed, and approved the final version of the manuscript. 
countries: present status and prospects. Theor. Appl. Genet. 127, 1263-1291. doi: 10.1007/s00122-014-2301-3

Agbicodo, E. M., Fatokun, C. A., Bandyopadhyay, R., Wydra, K., Diop, N. N., Muchero, W., et al. (2010). Identification of markers associated with bacterial blight resistance loci in cowpea [Vigna unguiculata (L.) Walp.]. Euphytica 175, 215-226. doi: 10.1007/s10681-010-0164-5

Andargie, M., Knudsen, J. T., Pasquet, R. S., Gowda, B. S., Muluvi, G. M., and Timko, M. P. (2014). Mapping of quantitative trait loci for floral scent compounds in cowpea (Vigna unguiculata L.). Plant Breed. 133, 92-100. doi: $10.1111 /$ pbr.12112

Andargie, M., Pasquet, R. S., Gowda, B. S., Muluvi, G. M., and Timko, M. P. (2011). Construction of a SSR-based genetic map and identification of QTL for domestication traits using recombinant inbred lines from a cross between wild and cultivated cowpea [V. unguiculata (L.) Walp.]. Mol. Breed. 28, 413-420. doi: 10.1007/s11032-011-9598-2

Andargie, M., Pasquet, R. S., Muluvi, G. M., and Timko, M. P. (2013). Quantitative trait loci analysis of flowering time related traits identified in recombinant inbred lines of cowpea (Vigna unguiculata). Genome 56, 289-294. doi: 10.1139/gen-2013-0028

Ba, F. S., Pasquet, R. S., and Gepts, P. (2004). Genetic diversity in cowpea [Vigna unguiculata (L.) Walp.] as revealed by RAPD markers. Genet. Res. Crop Evol. 51, 539-550. doi: 10.1023/B:GRES.0000024158.83190.4e

Boukar, O., Fatokun, C. A., Roberts, P. A., Abberton, M., Huynh, B.-L., Close, T. J., et al. (2015). "Cowpea," in Grain Legumes (Handbook of Plant Breeding 10), ed A. M. De Ron (New York, NY: Springer-Verlag), 219-250.

Boukar, O., Kong, L., Singh, B. B., Murdock, L., and Ohm, H. W. (2004). AFLP and AFLP-derived SCAR markers associated with Striga gesnerioides resistance in cowpea. Crop Sci. 44, 1259-1264. doi: 10.2135/cropsci2004.1259

Boukar, O., Massawe, F., Muranaka, S., Franco, J., Mayiza-Dixon, B., Singh, B., et al. (2011). Evaluation of cowpea germplasm lines for protein and mineral concentrations in grains. Plant. Genet. Res. 9, 515-522. doi: $10.1017 /$ S1479262111000815

Chen, X., Laudeman, T. W., Rushton, P. J., Spraggins, T. A., and Timko, M. P. (2007). CGKB: an annotation knowledge base for cowpea (Vigna unguiculata L.) methylation filtered genomic genespace sequences. BMC Bioinformatics 8:129. doi: 10.1186/1471-2105-8-129

Choumane, W., Winter, P., Weigand, F., and Kahl, G. (2000). Conservation and variability of sequence tagged microsatellites sites (STMS) from chickpea (Cicer aerietinum L.) within the genus Cicer. Theor. Appl. Genet. 101, 269-278. doi: $10.1007 / \mathrm{s} 001220051479$

Close, T. J., Luo, M., Lonardi, S., Alpert, M., Duma, D., Bozdag, S., et al. (2011). "Genome resources for cowpea genotype IT97 K-499-35," in Proceedings of Plant and Animal Genome Conference XIX P028 (San Diego, CA).

CRP GL (2012). CGIAR Research Program on Grain Legumes Proposal Leveraging Legumes to Combat Poverty, Hunger, Malnutrition and Environmental Degradation. Version 15 August 2012. Available online at: http://www.icrisat.org/crp/CRP3.5_Grain_Legumes_15Aug12.pdf

Diouf, D., and Hilu, K. W. (2005). Microsatellites and RAPD markers to study genetic relation- ship among cowpea breeding lines and local varieties in Senegal. Genet. Res. Crop Evol. 52, 1057-1067. doi: 10.1007/s10722-004-6107-z

Fall, L., Diouf, D., Fall-Ndiaye, M. A., Badiane, F. A., and Gueye, M. (2003). Genetic diversity in cowpea [Vigna unguiculata (L.) Walp.] varieties determined by ARA and RAPD techniques. Afr. J. Biotechnol. 2, 48-50. doi: 10.5897/AJB2003.000-1009

Fang, J., Chao, C.-C. T., Roberts, P. A., and Ehlers, J. D. (2007). Genetic diversity of cowpea [Vigna unguiculata (L.) Walp.] in four West African and USA breeding programs as determined by AFLP analysis. Genet. Res. Crop Evol. 54, 1197-1209. doi: 10.1007/s10722-006-9101-9

Fatokun, C. A., Boukar, O., Kamara, A., Coulibaly, O., Alene, A., Boahen, S., et al. (2012b). "Enhancing cowpea productivity and production in droughtprone areas of Sub-Saharan Africa," in Four Seasons of Learning and Engaging Smallholder Farmers: Progress of Phase 1, ed T. Abate (Nairobi: International Crops Research Institute for the Semi-Arid Tropics), 81-112.

Fatokun, C. A., Boukar, O., and Muranaka, S. (2012a). Evaluation of cowpea [Vigna unguiculata (L.) Walp.] germplasm lines for tolerance to drought. Plant Genet. Res. 10, 171-176. doi: 10.1017/S1479262112000214

Fatokun, C. A., Dariush, D., Menancio-Hautea, D. I., and Young, N. D. (1993). "A linkage map for cowpea [Vigna unguiculata (L.) Walp.] based on DNA markers," in Genetic Maps. Locus Maps of Complex Genomes, 6th Edn., ed S. J. O’Brien (New York, NY: Cold Spring Harbour Laboratory Press), 256-258.

Fatokun, C. A., Menancio-Hautea, D. I., Danesh, D., and Young, N. D. (1992). Evidence for orthologous seed weight genes in cowpea and mung bean based on RFLP mapping. Genetics 132, 841-846.

Fatokun, C. A., and Singh, B. B. (1987). Interspecific hybridization between Vigna pubescens and V. unguiculata (L.) Walp. through embryo culture. Plant Cell Organ Cult. 9, 229-233.

Fatokun, C. A., Young, N. D., and Myers, G. O. (1997). "Molecular markers and genome mapping in cowpea," in Advances in Cowpea Research, eds B. B. Singh, D. R. Mohan Raj, K. E. Dashiell, and L. E. N. Jackai (Ibadan: Co-publication of International Institute of Tropical Agriculture (IITA); Japan International Research Center for Agricultural Sciences (JIRCAS)), 352-360.

Ferry, R. L., and Singh, B. B. (1997). "Cowpea genetics: a review of the recent literature," in Advances in cowpea research, eds B. B. Singh, D. R. Mohan-Raj, K. E. Dashiell, and L. E. N. Jackai (Ibadan: Co-publication of International Institute of Tropical Agriculture (IITA); Japan International Research Center for Agricultural Sciences (JIRCAS)), 13-29.

Fotso, M., Azanza, J. L., Pasquet, R. S., and Raymond, J. (1994). Molecular heterogeneity of cowpea (Vigna unguiculata, Fabaceae) seed storage proteins. Plant Syst. Evol. 191, 39-56. doi: 10.1007/BF00985341

Ghalmi, N., Malice, M., Jacquemin, J. M., Ounane, S. M., Mekliche, L., and Baudoin, J. P. (2010). Morphological and molecular diversity within Algerian cowpea [Vigna unguiculata (L.) Walp.] landraces. Genet. Res. Crop Evol. 57, 371-386. doi: 10.1007/s10722-009-9476-5

Gioi, T. D., Boora, K. S., and Chaudhary, K. (2012). Identification and characterization of SSR markers linked to yellow mosaic virus resistance genes in cowpea (Vigna unguiculata). Int. J. Plant Res. 2, 1-8. doi: 10.5923/j.plant.20120201.01

He, C., Poysa, V., and Yu, K. (2003). Development and characterization of simple sequence repeat (SSR) markers and their use in determining relationships among Lycopersicon esculentum cultivars. Theor. Appl. Genet. 106, 363-373. doi: 10.1007/s00122-002-1076-0

Huynh, B.-L., Close, T. J., Roberts, P. A., Hu, Z., Wanamaker, S., Lucas, M. R., et al. (2013). Gene pools and the genetic architecture of domesticated cowpea. Plant Genome 6, 1-8. doi: 10.3835/plantgenome2013.03.0005

Huynh, B.-L., Ehlers, J. D., Ndeye, N. N., Wanamaker, S., Lucas, M. R., Close, T. J., et al. (2015). Genetic mapping and legume synteny of aphid resistance in African cowpea (Vigna unguiculata L. Walp.) grown in California. Mol. Breed. 35:36. doi: 10.1007/s11032-015-0254-0

Huynh, B.-L., Matthews, W., Ehlers, J. D., Lucas, M., Santos, J. P., Ndeve, A., et al. (2016). A major QTL corresponding to the $R k$ locus for resistance to root-knot nematodes in cowpea (Vigna unguiculata L. Walp.). Theor. Appl. Genet. 129, 87-95. doi: 10.1007/s00122-015-2611-0

Kongjaimun, A., Kaga, A., Tomooka, N., Somta, P., Shimizu, T., Shu, Y., et al. (2012a). An SSR-based linkage map of yardlong bean [Vigna unguiculata (L.) Walp. subsp. unguiculata sesquipedalis group] and QTL analysis of pod length. Genome 55, 81-92. doi: 10.1139/g11-078

Kongjaimun, A., Kaga, A., Tomooka, N., Somta, P., Vaughan, D. A., and Srinives, P. (2012b). The genetics of domestication of yardlong bean, Vigna unguiculata (L.) Walp. ssp. unguiculata cv.-gr. sesquipedalis. Ann. Bot. 109, 1185-1200. doi: 10.1093/aob/mcs048

Kongjaimun, A., Somta, P., Tomooka, N., Kaga, A., Vaughan, D. A., and Srinives, P. (2013). QTL mapping of pod tenderness and total soluble solid in yardlong bean [Vigna unguiculata (L.) Walp. subsp. unguiculata cv.-gr. sesquipedalis]. Euphytica 189, 217-223. doi: 10.1007/s10681-01 2-0781-2

Li, C. D., Fatokun, C. A., Ubi, B., Singh, B. B., and Scoles, G. J. (2001). Determining genetic similarities and relationships among cowpea breeding lines and cultivars by microsatellite markers. Crop Sci. 41, 189-197. doi: 10.2135/cropsci2001.411189x

Lucas, M. R., Diop, N. N., Wanamaker, S., Ehlers, J. D., Roberts, P. A., and Close, T. J. (2011). Cowpea-soybean synteny clarified through an improved genetic map. Plant Genome 4, 218-224. doi: 10.3835/plantgenome2011.06. 0019

Lucas, M. R., Ehlers, J. D., Huynh, B. L., Diop, N. N., Roberts, P. A., and Close, T. J. (2013a). Markers for breeding heat-tolerant cowpea. Mol. Breed. 31, 529-536. doi: $10.1007 / \mathrm{s} 11032-012-9810-\mathrm{Z}$ 
Lucas, M. R., Ehlers, J. D., Roberts, P. A., and Close, T. J. (2012). Markers for quantitative resistance to foliar thrips in cowpea. Crop Sci. 52, 2075-2081. doi:10.2135/cropsci2011.12.0684

Lucas, M. R., Huynh, B. L., da Silva Vinholes, P., Cisse, N., Drabo, I., Ehlers, J. D., et al. (2013b). Association studies and legume synteny reveal haplotypes determining seed size in Vigna unguiculata. Front. Plant Sci. 4:95. doi: 10.3389/fpls.2013.00095

Luo, R., Liu, B., Xie, Y., Li, Z., Huang, W., Yuan, J., et al. (2012). SOAPdenovo2: an empirically improved memory-efficient short-read de novo assembler. Gigascience 1:18. doi: 10.1186/2047-217X-1-18

Marechal, R. L., Mascherpa, J. M., and Steiner, F. (1978). Etude taxonomique d'un groupe complexe d'espèces des genres Phaseolus et Vigna (Pipillionaceae) sur la base de données morphologiques et polliniques, traitées par l'analyse informatique. Boissiera 28, 1-273.

Menancio-Hautea, D. I., Fatokun, C. A., Kumar, L., Danesh, D., and Young, N. D. (1993). Comparative genome analysis of mung bean (Vigna radiata L. Wilczek) and cowpea (V. unguiculata L. Walpers) using RFLP mapping data. Theor. Appl. Genet. 86, 797-810. doi: 10.1007/BF00212605

Menendez, C. M., Hall, A. E., and Gepts, P. (1997). A genetic linkage map of cowpea (Vigna unguiculata) developed from a cross between two inbred, domesticated lines. Theor. Appl. Genet. 95, 1210-1217.

Mignouna, H. D., Ng, Q., Ikea, J., and Thottapilly, G. (1998). Genetic diversity in cowpea as revealed by random amplified polymorphic DNA. J. Genet. Breed. 52, 151-159.

Muchero, W., Diop, N. N., Bhat, P. R., Fenton, R. D., Wanamaker, S., Pottorff, M., et al. (2009a). A consensus genetic map of cowpea [Vigna unguiculata (L.) Walp.] and synteny based on EST-derived SNPs. Proc. Natl. Acad. Sci. U.S.A. 106, 18159-18164. doi: 10.1073/pnas.0905886106

Muchero, W., Ehlers, J. D., Close, T. J., and Roberts, P. A. (2009b). Mapping QTL for drought stress-induced premature senescence and maturity in cowpea [Vigna unguiculata (L.) Walp.]. Theor. Appl. Genet. 118, 849-863. doi 10.1007/s00122-008-0944-7

Muchero, W., Ehlers, J. D., Close, T. J., and Roberts, P. A. (2011). Genic SNP markers and legume synteny reveal candidate genes underlying QTL for Macrophomina phaseolina resistance and maturity in cowpea [Vigna unguiculata (L) Walp.] BMC Genomics 12:8. doi: 10.1186/1471-2164-12-8

Muchero, W., Ehlers, J. D., and Roberts, P. A. (2010). QTL analysis for resistance to foliar damage caused by Thrips tabaci and Frankliniella schultzei (Thysanoptera: Thripidae) feeding in cowpea [Vigna unguiculata (L.) Walp.]. Mol. Breed. 25, 47-56. doi: 10.1007/s11032-009-9307-6

Muchero, W., Roberts, P. A., Diop, N. N., Drabo, I., Cisse, N., Close, T. J., et al. (2013). Genetic architecture of delayed senescence, biomass, and grain yield under drought stress in cowpea. PLoS ONE 8:e70041. doi: 10.1371/journal.pone.0070041

Nkongolo, K. K. (2003). Genetic characterization of Malawian cowpea [Vigna uncuguilata (L.) Walp.] landraces: diversity and gene flow among accessions. Euphytica 129, 219-228. doi: 10.1023/A:1021935431873

Ogunkanmi, L. A., Ogundipe, O. T., Ng, N. Q., and Fatokun, C. A. (2008). Genetic diversity in wild relatives of cowpea (Vigna unguiculata) as revealed by simple sequence repeats (SSR) markers. J. Food Agric. Environ. 6, 253-268.

Omo-Ikerodah, E. E., Fawole, I., and Fatokun, C. (2008). Genetic mapping of quantitative trait loci (QTLs) with effects on resistance to flower bud thrips (Megalurothrips sjostedti) in recombinant inbred lines of cowpea [Vigna unguiculata (L.) Walp.]. Afr. J. Biotechnol. 7, 263-270.

Ouédraogo, J. T., Gowda, B. S., Jean, M., Close, T. J., Ehlers, J. D., Hall, A. E., et al. (2002a). An improved genetic linkage map for cowpea (Vigna unguiculata L.) combining AFLP, RFLP, RAPD, biochemical markers, and biological resistance traits. Genome 45, 175-188. doi: 10.1139/g01-102

Ouédraogo, J. T., Maheshwari, V., Berner, D. K., St-Pierre, C. A., Belzile, F., and Timko, M. P. (2001). Identification of AFLP markers linked to resistance of (Vigna unguiculata L.) to parasitism by Striga gesnerioides. Theor. Appl. Genet. 102, 1029-1036. doi: 10.1007/s001220000499

Ouédraogo, J. T., Ouédraogo, M., Gowda, B. S., and Timko, M. P. (2012). Development of sequence characterized amplified region (SCAR) markers linked to race-specific resistance to Striga gesnerioides in cowpea (Vigna unguiculata L.). Afr. J. Biotechnol. 11, 12555-12562. doi: 10.5897/AJB12.805
Ouédraogo, J. T., Tignegre, J.-B., Timko, M. P., and Belzile, F. J. (2002b). AFLP markers linked to resistance against Striga gesnerioides race 1 in cowpea (Vigna unguiculata). Genome 45, 787-793. doi: 10.1139/g02-043

Panella, L., and Gepts, P. (1992). Genetic relationships within Vigna unguiculata (L.) Walp. based on isozyme analyses. Genet. Res. Crop Evol. 39, 71-88.

Pasquet, R. S. (1999). Genetic relationship among subspecies of Vigna unguiculata (L.) Walp. based on allozyme variation. Theor. Appl. Genet. 98, 1104-1119. doi: $10.1007 / \mathrm{s} 001220051174$

Pasquet, R. S. (2000). Allozyme diversity of cultivated cowpea Vigna unguiculata (L.) Walp. Theor. Appl. Genet. 101, 211-219. doi: 10.1007/s001220051471

Popelka, J. C., Gollasch, S., Moore, A., Molvig, L., and Higgins, T. J. V. (2006). Genetic transformation of cowpea (Vigna unguiculata L.) and stable transmission of the transgenes to progeny. Plant Cell Rep. 25, 304-312. doi: 10.1007/s00299-005-0053-x

Pottorff, M., Ehlers, J. D., Fatokun, C., Roberts, P. A., and Close, T. J. (2012a). Leaf morphology in cowpea [Vigna unguiculata (L.) Walp.]: QTL analysis, physical mapping and identifying candidate gene using synteny with model legume species. BMC Genomics 13:234. doi: 10.1186/1471-2164-13-234

Pottorff, M., Roberts, P. A., Close, T. J., Lonardi, S., Wanamaker, S., and Ehlers, J. D. (2014). Identification of candidate genes and molecular markers for heat-induced brown discoloration of seed coats in cowpea [Vigna unguiculata (L.) Walp]. BMC Genomics 15:328. doi: 10.1186/1471-216415-328

Pottorff, M., Wanamaker, S., Ma, Y. Q., Ehlers, J. D., Roberts, P. A., and Close, T. J. (2012b). Genetic and physical mapping of candidate genes for resistance to Fusarium oxysporum f.sp. tracheiphilum race 3 in cowpea [Vigna unguiculata (L.) Walp]. PLoS ONE 7:e41600. doi: 10.1371/journal.pone. 0041600

Quin, F. M. (1995). "Introduction," in Advances in Cowpea Research, eds B. B. Singh, D. R. Mohan-Raj, K. E. Dashiell, and L. E. N. Jackai (Ibadan: Copublication of International Institute of Tropical Agriculture (IITA);Japan International Research Center for Agricultural Sciences (JIRCAS)), ix-xv.

Rodrigues, M. A., Santos, C. A. F., and Santana, J. R. F. (2012). Mapping of AFLP loci linked to tolerance to cowpea golden mosaic virus. Genet. Mol. Res. 11, 3789-3797. doi: 10.4238/2012.August.17.12

Sawadogo, M., Ouédraogo, J. T., Gowda, B. S., and Timko, M. P. (2010). Genetic diversity of cowpea (Vigna unguiculata L. Walp.) cultivars in Burkina Faso resistant to Striga gesnerioides. Afr. J. Biotechnol. 9, 8146-8153. doi: 10.5897/ AJB10.1175

Simon, M. V., Benko-Iseppon, A. M., Resende, L. V., Winter, P., and Kahl, G. (2007). Genetic diversity and phylogenetic relationships in Vigna savi germplasm revealed by DNA amplification fingerprinting. Genome 50, 538-547. doi: 10.1139/G07-029

Singh, B. B. (2002). "Recent genetic studies in cowpea," in Challenges and Opportunities for Enhancing Sustainable Cowpea Production, ed C. A. Fatokun, S. A. Tarawali, B. B. Singh, P. M. Kormawa, and M. Tamo (Ibadan: Proceedings of the World Cowpea Research Conference III held at the International Institute of Tropical Agriculture (IITA)), 3-13.

Souleymane, A., Aken'Ova, M. E., Fatokun, C. A., and Alabi, O. Y. (2013). Screening for resistance to cowpea aphid (Aphis craccivora Koch) in wild and cultivated cowpea (Vigna unguiculata L. Walp.) accessions. Int. J. Sci. Environ. Technol. 2, 611-621. doi: 10.13140/2.1.4717.9207

Spencer, M. M., Ndiaye, M. A., Gueye, M., Diouf, D., Ndiaye, M., and Gresshoff, P. M. (2000). DNA-based relatedness of cowpea [Vigna unguiculata (L.) Walp.] genotypes using DNA amplification fingerprinting. Phys. Mol. Biol. Plant 6, 81-88.

Timko, M. P., Rushton, P. J., Laudeman, T. W., Bokowiec, M. T., Chipumuro, E., Cheung, F., et al. (2008). Sequencing and analysis of the gene-rich space of cowpea. BMC Genomics 9:103. doi: 10.1186/1471-2164-9-103

Tosti, N., and Negri, V. (2002). Efficiency of three PCR-based markers in assessing genetic variation among cowpea (Vigna unguiculata subsp. unguiculata) landraces. Genome 45, 268-275. doi: 10.1139/g01-146

Ubi, B. E., Mignouna, H., and Thottappilly, G. (2000). Construction of a genetic linkage map and QTL analysis using a recombinant inbred population derived from an inter-subspecific cross of a cowpea [Vina unguiculata (L.) Walp.]. Breed. Sci. 50, 161-173. doi: 10.1270/jsbbs.50.161 
Uma, M. S., Hittalamani, S., Murthy, B. C. K., and Viswanatha, K. P. (2009). Microsatellite DNA marker aided diversity analysis in cowpea [Vigna unguiculata (L.) Walp.]. Ind. J. Genet. Plant Breed. 69, 33-35.

Vaillancourt, R. E., and Weeden, N. F. (1992). Chloroplast DNA polymorphism suggests Nigerian center of domestication for the cowpea, Vigna unguiculata (Leguminosae). Am. J. Bot. 79, 1194-1199. doi: 10.2307/2445219

Varshney, R. K., Terauchi, R., and McCouch, S. R. (2014). Harvesting the promising fruits of genomics: applying genome sequencing technologies to crop breeding. PLoS Biol. 12:e1001883. doi: 10.1371/journal.pbio.1 001883

Xavier, G. R., Martins, L. M. V., Rumjanek, N. G., and Filho, F. R. F. (2005), Variabilidade genética em acessos de caupi analisada por meio de marcadores RAPD. Pesquisa Agropecuária Brasileira 40, 353-359. doi: 10.1590/S0100204X2005000400006

Xu, P., Hu, T., Yang, Y., Wu, X., Wang, B., Liu, Y., et al. (2011). Mapping genes governing flower and seedcoat color in asparagus bean (Vigna unguiculata ssp. sesquipedalis) based on SNP and SSR markers. HortScience 46, 1102-1104.

Xu, P., Wu, X., Wang, B., Hu, T., Lu, Z., Liu, Y., et al. (2013). QTL mapping and epistatic interaction analysis in asparagus bean for several characterized and novel horticulturally important traits. BMC Genet. 14:4. doi: 10.1186/14712156-14-4

Xu, P., Wu, X., Wang, B., Liu, Y., Quin, D., Ehlers, J. D., et al. (2010). Development and polymorphism of Vigna unguiculata ssp. unguiculata microsatellite markers used for phylogenetic analysis in asparagus bean [Vigna unguiculata ssp. sesquipedialis (L.) Verdc]. Mol. Breed. 25, 675-684. doi: 10.1007/s11032-0099364-x

Zannou, A., Kossou, D. K., Ahanchédé, A., Zoundjihékpon, J., Agbicodo, E., Struik, P. C., et al. (2008). Genetic variability of cultivated cowpea in Benin assessed by random amplified polymorphic DNA. Afr. J. Biotechnol. 7, 4407-4414. doi: 10.5897/AJB08.856

Conflict of Interest Statement: The authors declare that the research was conducted in the absence of any commercial or financial relationships that could be construed as a potential conflict of interest.

The reviewer MKP and handling Editor declared their shared affiliation, and the handling Editor states that the process nevertheless met the standards of a fair and objective review.

Copyright (C) 2016 Boukar, Fatokun, Huynh, Roberts and Close. This is an openaccess article distributed under the terms of the Creative Commons Attribution License (CC BY). The use, distribution or reproduction in other forums is permitted, provided the original author(s) or licensor are credited and that the original publication in this journal is cited, in accordance with accepted academic practice. No use, distribution or reproduction is permitted which does not comply with these terms. 